\title{
Pengaruh Implementasi Sistem Manajemen Mutu ISO 9001:2008 dan Kemampuan Mengajar Widyaiswara Terhadap Kompetensi Lulusan Diklat
}

\section{Dewi Setiawati}

\begin{abstract}
This research mainly aims to explore competencies of training graduated which focuses on factors that influence competencies of training graduates, such as the implementation of quality management system ISO 9001:2008 and teaching quality of Widyaiswara. The main research problem addressed in this study is how the implementation of quality management system ISO 9001:2008 and teaching quality of Widyaiswara contribute to competencies of training graduates, both partially and altogether. I conducting this research, explanatory survey method is used with questionairres using likert and interval scales as the data collection techniques, that are distributed to 51 graduates of training at PPPPTK Penjas dan BK. To analyse the data, the study employs PPM (Pearson Product Moment), to investigate the direct and non-direct correlations of dependent and independent variables. Significance tests are administered using $F$-test and t-test. The results show that (1) the impelementation of quality management system ISO 9001:2008 significantly influences competencies of training graduates; (2) teaching quality of Widyaiswara significantly influences competencies of training graduates; and (3) both the implementation of quality management system ISO 9001:2008 and teaching quality of Widyaiswara significantly influence competencies of training graduates.
\end{abstract}

Keywords: quality management, ISO 9001:2008, teaching, Widyaiswar.

\section{PENDAHULUAN}

Pola utama yang telah dikembangkan dalam melaksanakan sistem pendidikan dan pelatihan berorientasi pada analisa kebutuhan diklat. Dimana kebutuhan peserta diklat tergali sebelum pelatihan dimulai dan dilaksanakan secara terpadu dan berkelanjutan. Pola-pola kegiatan pendidikan dan pelatihan pun diterapkan untuk menentukan besarnya pengaruh proses pelaksanaan terhadap peningkatan kompetensi yang diperoleh peserta setelah mengikuti pendidikan dan pelatihan, meliputi materi pelatihan, kemampuan instruktur/fasilitator/widyaiswara, fasilitas pelatihan, peserta pelatihan, serta mutu proses pelatihan termasuk proses pembelajaran.

Simamora (1995:49) mengatakan bahwa "Program pelatihan dan pengembangan merupakan serangkaian aktivitas yang dirancang untuk meningkatkan pengetahuan, kemampuan, sikap dan kinerja individu, kelompok atau seluruh organisasi." Selain itu juga bahwa aktivitas pelatihan dan pengembangan ditujukan untuk membantu karyawan mempelajari keahlian baru atau memperbaiki keahlian yang sudah ada. Peningkatan pengetahuan merupakan hal penting dalam proses pendidikan dan pelatihan. Pengetahuan peserta tentang ketersediaan kesempatan kerja dan informasinya, kualitas pelatihan, motivasi kerja, kualitas lulusan pelatihan dan kewiraswastaan lulusan pelatihan merupakan variabel-variabel yang perlu diperhatikan untuk meningkatkan relevansi pelatihan dengan kesempatan kerja.

Kompetensi lulusan diklat adalah kemampuan melaksanakan sesuatu yang diperoleh melalui pendidikan dan atau latihan. Dalam kompetensi menunjukan pada perbuatan yang rasional dan memenuhi spesifikasi tertentu dalam melaksanakan tugas-tugas kependidikan. Berkaitan dengan hal tersebut diatas, kompetensi lulusan diklat mampu meningkatkan pengetahuan dan mempelajari keterampilan baru atau memperbaiki keterampilan yang sudah ada, dan kemudian mendiseminasikannya dalam lingkungan kerja.

ISO 9001:2008 merupakan sistem manajemen dengan pendekatan kepuasan pelanggan. Gaspersz (2003:75) mengemukakan sistem manajemen mutu ISO 9001:2000, yang dijabarkan dalam delapan prinsip yaitu: (1) Fokus Pelanggan; (2) Kepemimpinan; (3) Keterlibatan orang; (4) Pendekatan Proses; (5) Pendekatan Sistem terhadap Manajemen; (6) Peningkatan Terus Menerus; (7) Pendekatan Faktual dalam Pembuatan Keputusan; (8) Hubungan Pemasok yang Saling Menguntungkan.

Mengajar dan belajar adalah dua peristiwa yang berbeda, akan tetapi antara keduanya terdapat hubungan yang erat sekali. Menurut Hamalik (2003:48) mengatakan bahwa: "Mengajar merupakan suatu 
aktivitas mengorganisasikan lingkungan sebaik-baiknya dan menghubungkan dengan anak sehingga terjadi belajar mengajar". Tugas widyaiswara identik dengan tugas mengajar lainnya, hanya saja dibedakan dari status dan sasaran pengajarannya. Adapun yang dimaksud dengan kemampuan mengajar widyaiswara dalam penelitian ini adalah potensi widyaiswara meliputi pengetahuan, keterampilan serta sikap yang baik dalam melaksanakan tugas mengajarnya. Hal ini didukung oleh Castetter (1991:278) yang mengemukakan bahwa knowledge, skills attitudes require for effective performance, (pengetahuan, keterampilan dan sikap dibutuhkan untuk mewujudkan kinerja yang efektif).

Berdasarkan data empiris di lapangan menunjukan bahwa peserta diklat belum menunjukan peningkatan kompetensi yang optimal. Banyak faktor-faktor yang mempengaruhi Kompetensi Lulusan Diklat diantaranya Implementasi Sistem Manajemen Mutu ISO 9001:2008 dan Kemampuan Mengajar Widyaiswara. Berdasarkan kenyataan tersebut, penulis tertarik untuk mengadakan penelitian seberapa besar pengaruh implementasi sistem manajemen mutu ISO 9001:2008 dan kemampuan mengajar widyaiswara terhadap kompetensi lulusan diklat.

Secara lebih rinci pokok masalah di atas dapat dirumuskan dalam bentuk pertanyaan-pertanyaan penelitian sebagai berikut:

1. Seberapa besar pengaruh implementasi sistem manajemen mutu ISO 9001:2008 terhadap kompetensi lulusan diklat?

2. Seberapa besar pengaruh kemampuan mengajar widyaiswara terhadap kompetensi lulusan diklat?

3. Seberapa besar pengaruh implementasi sistem manajemen mutu ISO 9001:2008 dan kemampuan mengajar widyaiswara secara simultan terhadap kompetensi lulusan diklat?

\section{METODOLOGI PENELITIAN}

Metode penelitian yang digunakan dalam penelitian ini adalah metode explanatory survey method, sehingga dapat diperoleh informasi mengenai pengaruh implementasi sistem manajemen mutu ISO 9001:2008 dan kemampuan mengajar widyaiswara terhadap kompetensi lulusan diklat di PPPPTK Penjas dan BK. Pendekatan metode ini menggunakan pendekatan kuantitatif untuk mengukur dan menggabungkan variabelvariabel penelitian, dengan mencatat dan menganalisis data dan hasil penelitian dengan perhitungan statistik.

\section{HASIL DAN PEMBAHASAN PENELITIAN}

Pembahasan merupakan kajian terhadap hasil penelitian yang ada hubungannya dengan jawaban terhadap permasalahan penelitian.

\section{Sistem Manajemen Mutu ISO 9001:2008}

Hasil penelitian menunjukkan bahwa secara umum, Implementasi Sistem Manajemen Mutu ISO 9001:2008 berada dalam kondisi sangat baik dengan perolehan skor rata-rata 4,48 sedangkan secara rinci diperoleh nilai skor rata-rata masing-masing aspek yaitu program diklat dengan skor 4,60, proses diklat 4,50, lingkungan dan sumber daya diklat 4,49 ketiganya termasuk kategori sangat baik, kemudian kepentingan peserta diklat dan kepuasaan peserta diklat dengan perolehan rata-rata skor 4,40 dam 4,47 termasuk kategori sangat baik, aspek staf penyelenggara diklat dan standar-standar diklat dengan perolehan skor 4,42 dan 4,54 termasuk kategori sangat baik.

2. Kemampuan Mengajar Widyaiswara

Secara umum kemampuan mengajar widyaiswara telah menunjukkan kemampuan yang sangat baik dengan angka skor rata-rata 4,38. Kemampuan mengajar widyaiswara tersebut meliputi Aspek Persiapan Pembelajaran yang memperoleh skor 4,4 termasuk kategori sangat baik, pelaksanaan pembelajaran 4,54 dan termasuk kategori sangat baik, sedangkan untuk aspek pengevaluasian kegiatan belajar dengan 4,2 yang termasuk kategori baik. Dalam melaksanakan kegiatan evaluasi ini widyaiswara dituntut untuk memiliki kemampuan yang utama. Hal ini senada dengan pendapat yang dikemukakan Gagne (1977:69) yang mengemukakan bahwa dalam kegiatan pembelajaran terdapat tiga kemampuan pokok yang dituntut dari seorang guru sebagai pengelola pembelajaran, yaitu: 1) merencanakan kegiatan pembelajaran, 2) melaksanakan kegiatan pembelajaran, dan 3) menilai kegiatan pembelajaran. Dengan adanya kegiatan evaluasi ini kelemahan-kelemahan dapat diperbaiki dan bersifat sebagai feedback bagi peserta diklat.

3. Kompetensi Lulusan Diklat

Hasil penelitian menunjukkan bahwa untuk aspek kognitif sebesar 4,17 termasuk kategori baik, sedang aspek afektif memeproleh skor sebesar 4,33 termasuk kategori sangat baik dan aspek psikomotorik memperoleh skor rata-rata sebesar 4,17 yang kategori baik. Secara umum Kompetensi Lulusan Diklat di Lingkungan PPPPTK Penjas dan BK termasuk kategori sangat baik, dengan skor rata-rata 4,22. 
Adanya peningkatan kemampuan sebagai hasil dari pendidikan dan latihan dikemukakan oleh Soekidjo Notoatmodjo (2003:31) berpendapat bahwa "pendidikan dan pelatihan adalah suatu proses yang akan menghasilkan suatu perubahan perilaku sasaran diklat." Secara konkret perubahan perilaku itu berbentuk peningkatan kemampuan dari sasaran diklat. Kemampuan ini mencakup kognitif, afektif maupun psikomotor. Dengan demikian Mutu hasil belajar dalam pendidikan dan pelatihan merupakan kompetensi atau kemampuan yang pada dasarnya merupakan pengetahuan, ketrampilan dan nilai-nilai dasar (sikap) yang direfleksikan dalam kebiasaan.

4. Pengaruh Sistem Manajemen Mutu ISO 9001:2008 terhadap Kompetensi Lulusan Diklat

Berdasarkan hasil penelitian yang telah dilakukan, diperoleh koefisien korelasi antara sistem manajemen mutu ISO 9001:2008 terhadap kompetensi lulusan diklat sebesar 0,554 yang berarti pengaruhnya sedang.

Hasil perhitungan análisis koefisien determinasi, diperoleh hasil koefisien determinasi sebesar 30,69 $\%$, yang berarti variabel sistem manajemen mutu ISO 9001:2008 memberi pengaruh sebesar 30,69\% terhadap variabel kompetensi lulusan diklat, sedangkan sisanya 69,31\% ditentukan oleh variabel lain, misalnya dengan meningkatkan program diklat yang sesuai dengan tuntutan profesi dan perkembangan sistem pendidikan, meningkatkan proses diklat yang dirancang secara sistematis dan dengan ditunjang oleh peningkatan sarana dan prasarana sebagai sumber daya diklat yang mendukung keterlaksanaan proses diklat dengan efektif dan efisien.

5. Pengaruh Kemampuan Mengajar Widyaiswara terhadap Kompetensi Lulusan Diklat

Berdasarkan temuan penelitian bahwa kemampuan mengajar widyaiswara berkontribusi signifikan terhadap kompetensi lulusan diklat sebesar 0,426 yang berarti pengaruhnya sedang.

Hasil koefisien determinasi sebesar $18,15 \%$, yang berarti besarnya sumbangan variabel kemampuan mengajar widyaiswara terhadap kompetensi lulusan diklat adalah 18,15\%, dan sisanya sebesar 81,85\% ditentukan oleh variabel lain.

Adanya temuan bahwa Kemampuan Mengajar Widyaiswara ternyata merupakan bagian dari unsur yang dapat mempengaruhi Kompetensi Lulusan Diklat dan mendorong peserta diklat untuk dapat mengaplikasikan ilmu baik yang bersifat teori maupun praktek di tempat kerja, oleh karena itu untuk mengoptimalkan Kompetensi Lulusan Diklat tersebut, maka widyaiswara tersebut harus memiliki kemampuan mengajar yang sangat baik yang meliputi ke tiga aspek yaitu persiapan pembelajaran, pelaksanaan dan pengevaluasian kegiatan belajar.

6. Pengaruh Sistem Manajemen Mutu ISO 9001:2008 dan Kemampuan Mengajar Widyaiswara terhadap Kompetensi Lulusan Diklat

Besarnya pengaruh implementasi sistem manajemen mutu ISO 9001:2008 dan kemampuan mengajar widyaiswara guru terhadap kompetensi lulusan diklat yang dihitung dengan koefisien korelasi ganda sebesar 0,584 (sedang).

Secara bersama-sama implementasi sistem manajemen mutu ISO 9001:2008 dan kemampuan mengajar widyaiswara berkontribusi signifikan terhadap kompetensi lulusan diklat sebesar 34,10\%, sedangkan sisanya $65,90 \%$ merupakan pengaruh yang datang dari faktor-faktor lain seperti: budaya organisasi, iklim kerja, kepuasan, motivasi, konsep diri, efektivitas, tingkat pendidikan, ketrampilan, sarana dan sarana serta masih banyak faktor lainnya.

Berdasarkan temuan penelitian tersebut dapat disimpulkan bahwa Implementasi Sistem Manajemen Mutu ISO 9001:2008 dan Kemampuan Mengajar Widyaiswara mempengaruhi Kompetensi Lulusan Diklat. Kaitannya dengan kompetensi lulusan bahwa Kemampuan Mengajar Widyaiswara dapat mempengaruhi kompetensi peserta diklat yang diajarnya. Widyaiswara yang memiliki kemampuan mengajar yang baik tentu akan menunjukkan sikap professional dalam proses pembelajarannya, dimana dalam melaksanakan proses pembelajaran akan diawali dengan perencanaan pembelajaran yang baik.

\section{KESIMPULAN DAN SARAN}

Berdasarkan temuan-temuan yang diperoleh dari hasil pengolahan dan analisis data dari penelitian yang berjudul "Pengaruh Implementasi Sistem Manajemen Mutu ISO 9001:2008 dan Kemampuan Mengajar Widyaiswara terhadap Kompetensi Lulusan Diklat", maka penulis dapat mengambil kesimpulan yang tentunya merujuk pada rumusan masalah yang telah diajukan pada penelitian ini, yaitu, sistem Manajemen Mutu ISO 9001:2008 berkontribusi secara signifikan terhadap Kompetensi Lulusan Diklat Peningkatan Kompetensi Guru Penjas SMP di PPPPTK Penjas dan BK. Besarnya sumbangan sebesar 30,69\%, hal ini berarti bahwa Kompetensi lulusan diklat guru ditentukan oleh Sistem Manajemen Mutu ISO 9001:2008. 
Kemampuan Mengajar Widyaiswara yang berada di Lingkungan PPPTK Penjas dan BK berkontribusi secara signifikan terhadap Kompetensi Lulusan Diklat Peningkatan Kompetensi Guru Penjas SMP dengan besarnya sumbangan 18,15\%. Hal ini berarti bahwa variabel Kemampuan Mengajar Widyaiswara turut menentukan Kompetensi Lulusan Diklat Peningkatan Kompetensi Guru Penjas SMP.

Sistem Manajemen Mutu ISO 9001:2008 dan Kemampuan Mengajar Widyaiswara secara bersamasama memberikan kontribusi sebesar 34,10\% dan sisanya sebesar 65,90\% ditentukan oleh faktor lain, misalnya iklim kerja, fasilitas kerja, kompensasi dan rekrutmen, motivasi, efikasi diri, kompentensi dan lainlain. Dengan demikian peningkatan Kompetensi Lulusan Diklat guru dapat direncanakan dengan meningkatkan Sistem Manajemen Mutu ISO 9001:2008 dan pengembangan Kemampuan Mengajar Widyaiswara.

\section{DAFTAR PUSTAKA}

Atmodiwiryo, S. (2005). Manajemen Pendidikan Indonesia. Jakarta: Ardadizya Jaya.

Castetter, W. B. (1996). The Personnel Function in Educational Administration. New York: McMillan Publishing Co. Inc

Gagne, Robert M. (1977). The Conditioning of Learning, New York: Holt Rinehart and Winston

Gaspersz, Vincent. (2003). ISO 9001:2000 Continual Quality Improvement, Jakarta: Gramedia Pustaka Utama

Hamalik, Oemar. (2001). Proses Belajar Mengajar, Jakarta: Salemba Empat

Mulyasa, E. (2008). Menjadi Guru Profesional. Menciptakan Pembelajaran Kreatif dan Menyenangkan. Bandung: Remaja Rosdakarya.

Simamora, H. (1995). Manajemen Sumber Daya Manusia, Yogyakarta, Penerbit STIE YPK

Sagala. S. (2000). Administrasi Pendidikan Kontemporer. Bandung: Alfabeta

Sallis. E (2006), Total Quality Management in Educational. Jogjakarta: IRCiSoD 